\title{
Design of Temperature Control System of HFO Fuel Type on Ship Based PLC
}

\author{
Eddy Setyo Koenhardono ${ }^{1}$, Juniarko Prananda ${ }^{2}$, M. Arif Fachruddin ${ }^{3}$
}

\begin{abstract}
Fuel is one of the important component of ship operations. The overall operating cost of the vessel, approximately $60 \%$ consists of fuel costs. The unavailability of fuel causes the ship's operational processes to be adversely affect the company from both technical and material terms. It is a bad condition if ship's fuel does fulfilled the time schedule. To reach the fuel operation criteria and help ships crew operate the fule system, we propose the method to control fuel system. Our objection is how to make ship fuel system can be operated automatically as well as temperature control system on the vessel using PLC. This automation system relies on high level sensors and low level sensors as well as temperature sensors in each tank to trigger the performance of each of the fuel system support equipment such as pumps, valves, heaters. The sensor and thermometer in the tank will be processed by the PLC prior to controlling the equipment. Processing is sequentially adjusted to the processing sequence of HFO fuel. Processing is done based on existing ship data but still using the control manually. As well as recommendations from the classification bureau and machine manufacturers. The work process of the system can be monitored as a whole through Human Machine Interface. The monitor consists of a view that contains all the work of the existing system. The PLC used is OMRON CPM2A with CXProgrammer software and CX-Designer monitor. So by simply using a control device in the form of PLC, HFO processing can be operated automatically both when the ship is idle or in sail condition.
\end{abstract}

Keywords-Heavy Fuel Oil, Fuel System, PLC, Automation, Control.

\section{INTRODUCTION}

$\mathrm{M}$ ain engine is one of the most important equipment on ship[1], [2]. Ship fuel transfer and separation system is fuel process before used on diesel engine. This system is recommended for ship with 380cst fuel [3]-[5]. The system works by continuously treatment before used. Such as separate residue, heated, and maintain fuel viscosity. The fuel process will gice an impact to fuel properties then influence the engine performance and durability[6], [7].

The fuel temperature control and transfer system is one of several on board system that can be automatically controlled. Fuel treatment system can be controlled because the system works sequentially based on regulated procedure. Based on sequential work, programmable logic controller in one tools that compatible as a new fuel treatment system[8].

In this research, fuel treatment system is controlled by programmable logic controller in the form of prototype modelling in laboratory scale. This system is able to control, supervise, and restore the fuel treatment system.

Eddy Setyo Koenhardono is with Departement of Marine Engineering, Institut Teknologi Sepuluh Nopember, Surabaya, 60111, Indonesia. E-mail: eddy-koen@its.ac.id

Juniarko Prananda is with Departement of Marine Engineering, Institut Teknologi Sepuluh Nopember, Surabaya, 60111, Indonesia. Email: juniarko@ne.its.ac.id

M. Arif Fachruddin is with Departement of Marine Engineering, Institut Teknologi Sepuluh Nopember, Surabaya, 60111, Indonesia. Email:mariffachruddin16@mhs.ne.its.ac.id
A. Prototype component of HFO Temperature Control amd Transfer System

To built the prototype, we use several component below

- MCB 1 Phase (2A)

- PLC (Omron CPM2A CDR30)

- Power Supply (24VDC, 12VDC)

- Relay DC (24VDC)

- Solenoid Valve (24VDC, 220VAC)

- Water Pump (12VDC)

- Level Censor (24VDC)

Prototype of HFO temperature control and transfer system is made according to the rules and regulations. This equipment uses 6 tanks made from acrylic as 1 storage tank, 2 settling tanks, 2 service tanks, and 1 sludge tank. 3 pieces of water pump with specification of $12 \mathrm{VDC}, 4 \mathrm{~L} / \mathrm{Min}$ capacity, and 60 watt power.

\section{B. HFO Temperature Control and Transfer System} Circuit

The control system work as a control device for fuel oil system. The series of inputs and outputs on the device is used as a signal for the PLC decision makers to execute a command [3]. Input served as an indication for the tank demand and PLC output will trigger the pump and valve to turning on based on PLC ladder diagram that has been program. Input used on this equpment as much as 15 pieces, and the output of 17 pieces. Table 1 is a table of input and table 2 is a tabel of output PLC. 
TABLE 1.

INPUT PLC

\begin{tabular}{ccc}
\hline No & $\begin{array}{c}\text { Address } \\
\text { Input }\end{array}$ & Description \\
\hline 1 & 0.00 & Push button system on \\
2 & 0.01 & Push button main engine on \\
Switch button stop \\
3 & 0.02 & Low level censor settling tank 1 \\
4 & 0.03 & High level censor settling tank 1 \\
5 & 0.04 & Low level censor settling tank 2 \\
6 & 0.05 & High level censor settling tank 2 \\
7 & 0.06 & Low level censor service tank 1 \\
8 & 0.07 & High level censor service tank 1 \\
9 & 0.08 & High level censor service tank 2 \\
10 & 0.09 & Settling tank 1 thermometer \\
11 & 0.10 & Settling tank 2 thermometer \\
12 & 1.00 & Service tank 1 thermometer \\
13 & 1.01 & Service tank 2 thermometer \\
14 & 1.02 &
\end{tabular}

TABLE 2.

OUTPUT PLC

\begin{tabular}{ccc}
\hline No & $\begin{array}{c}\text { Address } \\
\text { Input }\end{array}$ & Description \\
\hline 1 & 10.00 & Valve before settling tank 1 \\
2 & 10.01 & Valve before settling tank 2 \\
3 & 10.02 & Valve drain settling tank 1 \\
4 & 10.03 & Valve drain settling tank 2 \\
5 & 10.04 & Valve after settling tank 1 \\
6 & 10.05 & Valve after settling tank 2 \\
7 & 10.06 & Valve before service tank 1 \\
8 & 10.07 & Valve before service tank 2 \\
9 & 11.00 & Valve after service tank 1 \\
10 & 11.01 & Valve after service tank 2 \\
11 & 11.02 & Transfer pump \\
12 & 11.03 & Separation pump \\
13 & 11.04 & Supply pump \\
14 & 11.05 & Heater in settling tank 1 \\
15 & 11.06 & Heater in settling tank 2 \\
16 & 11.07 & Heater in service tank 1 \\
17 & 11.08 & Heater in service tank 2 \\
\hline
\end{tabular}

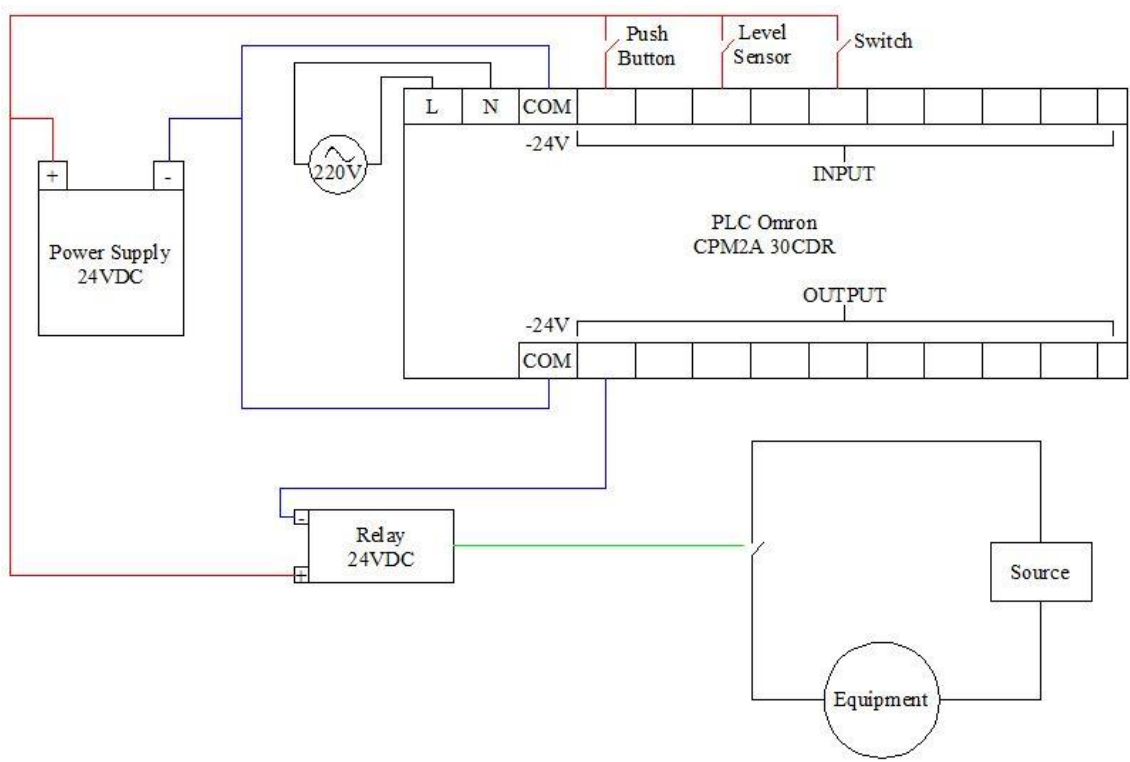

Figure 1. Wiring diagram. 
The function of power supply used to provide power or electricity supply to the equipment. The supply of electricity used is AC and DC power supply[1]. AC power supply is used to run the PLC, valve with AC supply, and DC power supply.

While the supply of DC power to run equipment such as DC relays, pump, valve with DC supply, and input/output modul on PLC. Voltage to the AC power used is equal to 220VAC while the voltage to the DC power used is equal to 24VDC. For DC electrical equipment, the applied voltage is equal to $12 \mathrm{VDC}$.

\section{METHOD}

The first stage in this research is transform fuel treatment process become logic control function (ladder diagram) using programmable logic control software. These functions include the relationship between tank conditions and equipments. The second stage is simulate the logic control function using simulator. The simulation of logic control function is aimed to assure the function match with regulated procedure. The third stage is design human machine interface. The interface have function for monitoring and data recording. The fourth stage is create the modelling system in prototype scale for laboratory.

In this research, HFO temperature control and transfer system will be analyzed based on 3 conditions, those are:
- Condition A, Transfer system. Fuel transferred from storage tank to fulfill 2 settling tanks.

- Condition B, Separation system. Fuel settled for 24 hours in settling tank and then transferred to fulfill 2 service tanks.

- Condition C, Supply system. Fuel transferred from service tank to supply main engine demand and each tank prepared for 8 hours capacity.

- Condition D, Temperature control. Fuel temperature will be controlled by thermometer and heater automatically.

\section{RESULTS AND DISCUSSION}

1.1.Condition A, Transfer system. Fuel transferred from storage tank to fulfill 2 settling tanks.

The main purpose of fuel transfer system is to transfer fuel from storage tank to fulfill 2 settling tanks. Transfer system is activated when there is a fuel demand from settling tank indicated by low level censor on each settling tank. There are several conditions that should be fulfilled before transfer system can be operated. Include the condition when tanks is available or unavailable. Each condition has each equipment work scenario such as valves and pumps [3]. Logic control function should be available for entire fuel oil transfer system. Work logic of fuel transfer system is shown in Figure 2

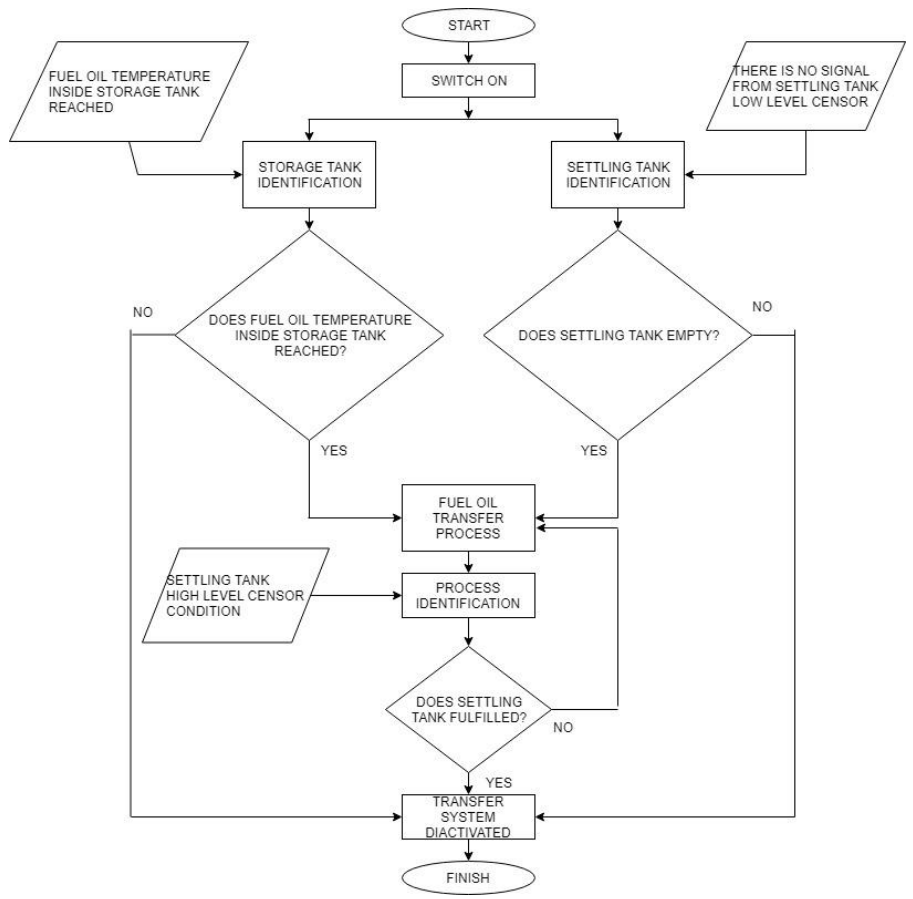

Figure 2. Work logic of condition A, transfer system.

As shown in Figure 2., after the switch of system on, system will identificate both storage and settling tank. At storage tank, identification done with fuel oil temperature inside storage tank reached. Settling tank identificated by signal from settling tank low level censor. If fuel oil temperature inside storage tank reached and settling tank in empty condition, fuel oil transfer process will activated. When transfer process activated, transfer pump will work and valve before settling tank will open and let the fuel fill the settling tank. Then doing identification affected by transfer process with signal from settling tank high level censor. If settling tank was not fulfilled yet, transfer process will keep on. If settling tank fulfilled, transfer process diactivated. 
1.2. Condition B, Separation system. Fuel settled for 24 hours in settling tank and then transferred to fulfill 2 service tanks.

The main purpose of fuel oil separation system is to transfer fuel oil from settling tank to fulfill 2 service tanks with 8 hours capacity. Separation system is activated when there is a fuel oil demand from service tank indicated by low level censor on each service tank. There are several conditions that should be fulfilled before separation system can be operated. Include the condition when tanks is available or unavailable. Did the fuel oil was already treated inside settling tank or not yet. Such as settled for 24 hours, heated, separated, and etc. Another purpose is to separate water contaminant inside fuel oil. Heaters should be used in settling tanks and before separation unit with different specific temperature [1]. Logic control function should be available for entire fuel oil separation system. Work logic of fuel oil separation system is shown in Figure 3.

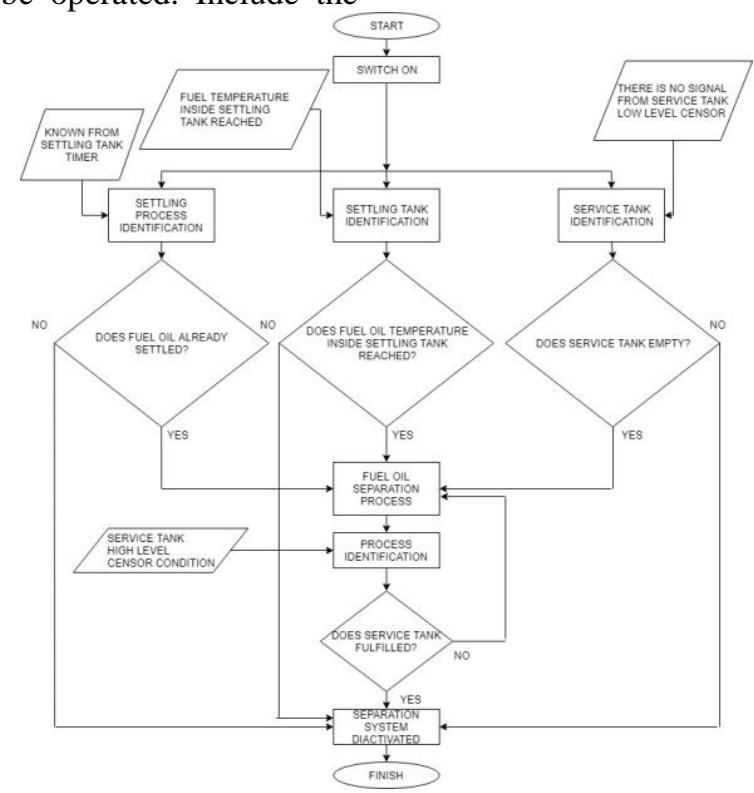

Figure 3. Work logic of condition of separation system.

As shown on Figure 3., after the system goes on, system will do identification on 3 condition. Settling tank, settling process, and service tank identification. Settling process identificated by timer from the system. Settling process should be done in 24 hours according to the rules. Settling tank identificated by fuel oil temperature inside settling tank. Does the temperature reach the set point or not yet. Service tank identificated by signal from service tank low level censor. If fuel oil alreay settled for 24 hours, temperature has reached set point, and service tank in empty condition, fuel oil separation process will be activated. When separation process activated, separator pump will work and valve before service tank will open and let the fuel fill the service tank. Then doing identification affected by separation process with signal from service tank high level censor. If service tank was not fulfilled yet, separation process will keep on. If service tank fulfilled, separation process will be diactivated.

1.3. Condition C, Supply system. Fuel transferred from service tank to supply main engine demand and each tank prepared for 8 hours capacity.

The main purpose of fuel oil service system is to fulfill main engine demand for running. Fuel oil transferred from service tank to main engine with several condition. The logic control function of fuel oil service system should be available for main engine demand before it start. There are several conditions that must be fulfilled for fuel oil before used by main engine. The condition is related to engine demand and the availability of service tanks. Work logic of fuel oil service system is shown in Figure 4. 


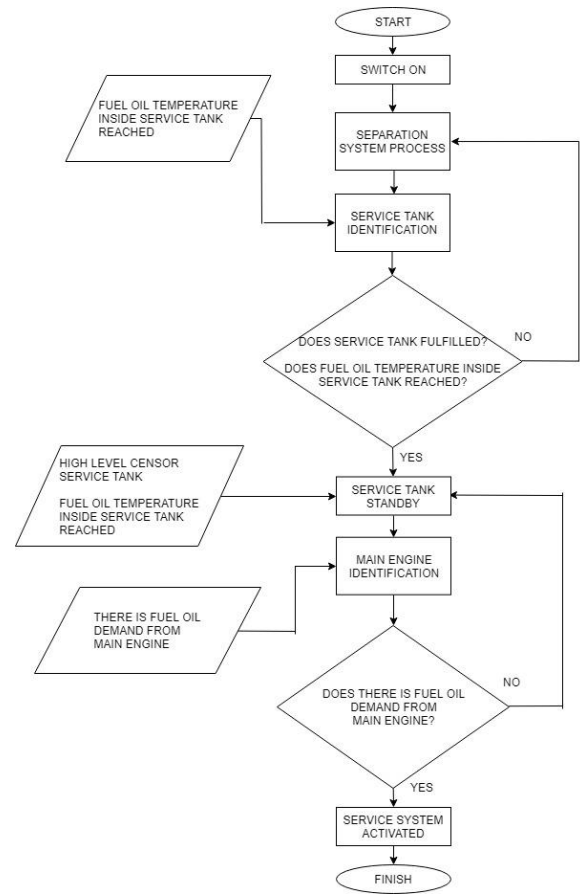

Figure 4. Work logic of condition of service system.

As shown on Figure 4., after switch of the system turned on, service tank identificated by fuel oil temperature inside service tank. If service tank was not yet fulfill, system will return to separation process until service tank fulfilled. After service tank fulfilled, if there is no demand from main engine, fuel oil will be standed by in service tank. If there is demand from main engine and fuel oil temperaure inside service tank was reached, service system will be activated to supply fuel oil from service tank to main engine for combustion process.
1.4. Condition D, Fuel temperature will be controlled by thermometer and heater automatically.

The main purpose of temperature contol is to heat the fuel until reach set point automatically. Fuel oil shoul be heated until reach set point at different location. Started from storage tank, settling tank, service tank, until before transferred to main engine combustion chamber. Work logic of fuel oil temperature control is shown in Figure 5.

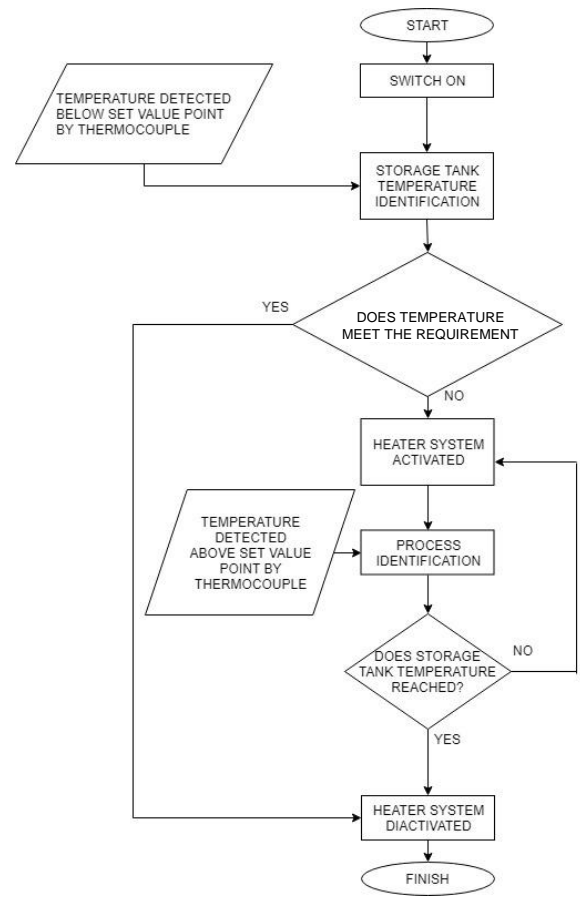

Figure 5. Work logic of condition of temperature control. 
As shown on Figure 5., after system start, thermocouple will detect the fuel oil temperature on each tank. Storage tank, 2 settling tanks, 2 service tanks, and before main engine. Identification done by fuel oil temperature inside each tank. If the fuel oil temperature reached set point, heater will be diactivated. If fuel oil temperature didn't reach set point, heater will be activated until it reach set point and diactivated.

\subsection{Fuel oil interface system}

Fuel oil interface system is an interface panel that allows crew to control and monitor fuel oil system from engine control room. For simple design, fuel interface divided into several sub-systems. There are switch panel, transfer system, separation system, and service system.

Switch panel is the initial appearance of the interface design. Switch panel consist of push button to turning on the system, push button to turning on the main engine, and stop button. also there are lamp indicator that indicate the system was already on or not yet. Switch panel interface is shown in Figure 6.

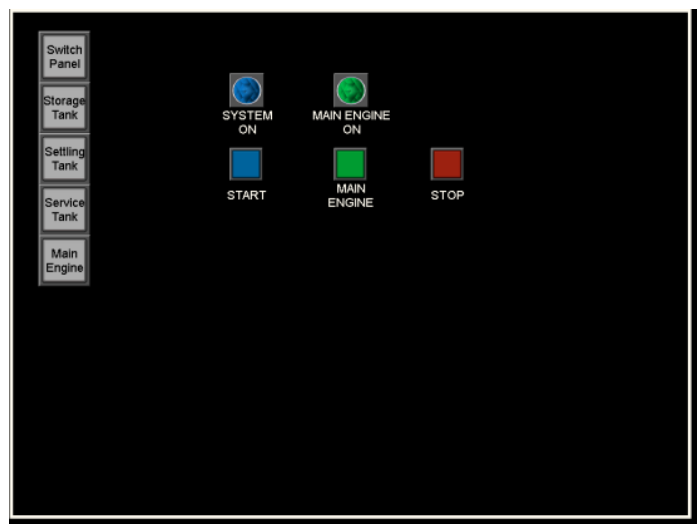

Figure 6. Switch panel interface.

Transfer system menu is an interface for control and monitoring transfer process from storage tank to settling tank. There are several objects in transfer system menu, such as storage tank, transfer pump. Transfer system menu is shown in Figure 7.

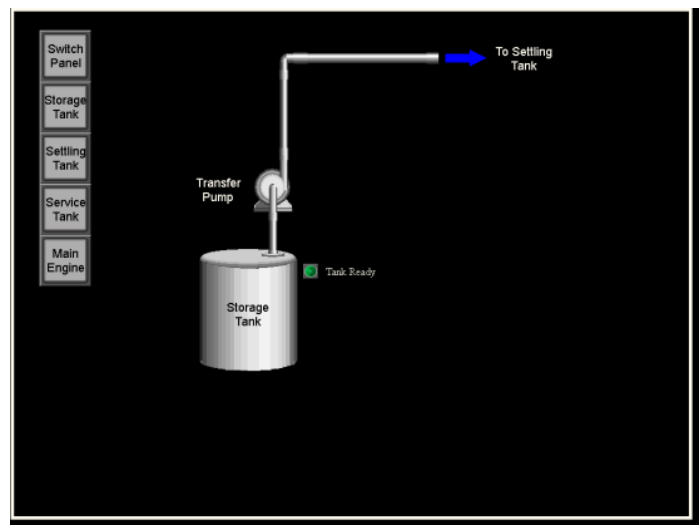

Figure 7. Transfer system menu.

Separation system menu is an interface for control and monitoring separation process from settling tank to the service tank. There are several objects in separation system menu, such as settling tanks, sludge tank, valves, separator pump, and heater. Separation system menu is shown in Figure 8.

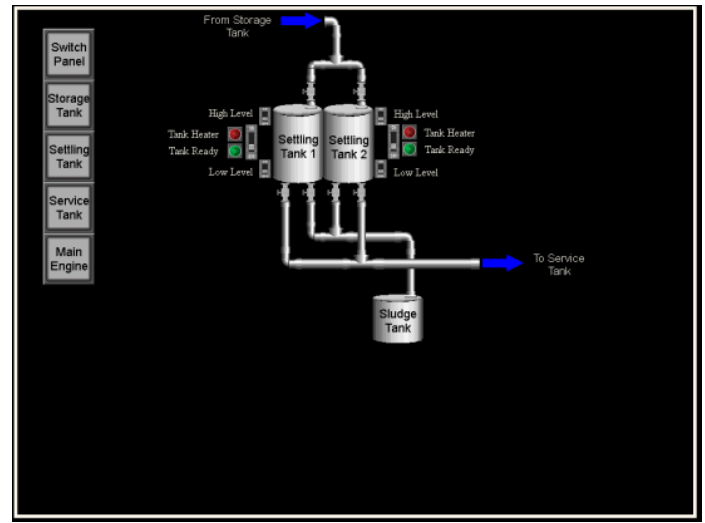

Figure 8. Separation system menu.

Service system menu is an interface for monitoring of supply process from service tank to main engine. In service system menu consists equipments such as service tanks, pump, valves, and main engine. Service system menu is shown in Figure 9.

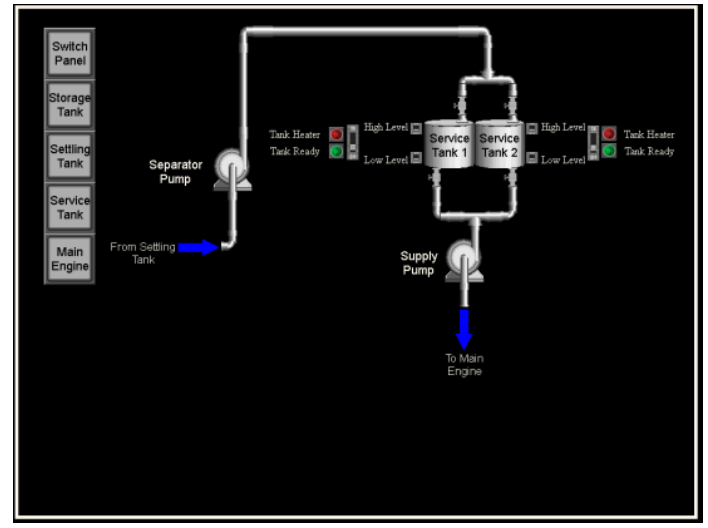

Figure 9. Service system menu.

1.6.Fuel oil system prototype

Output of this research is a prototype of fuel oil control system. The prototype consists of equipment that listed on table 1 and table 2 . Including control panel and fuel system made of acrylic material. Prototype will be able to demonstrate the fuel oil system on ship with HFO type. The prototype and control panel is shown in Figure 10.

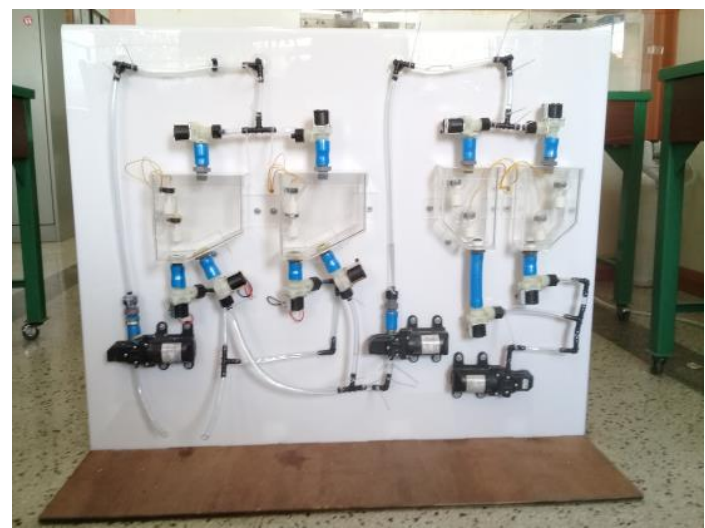

(a) 


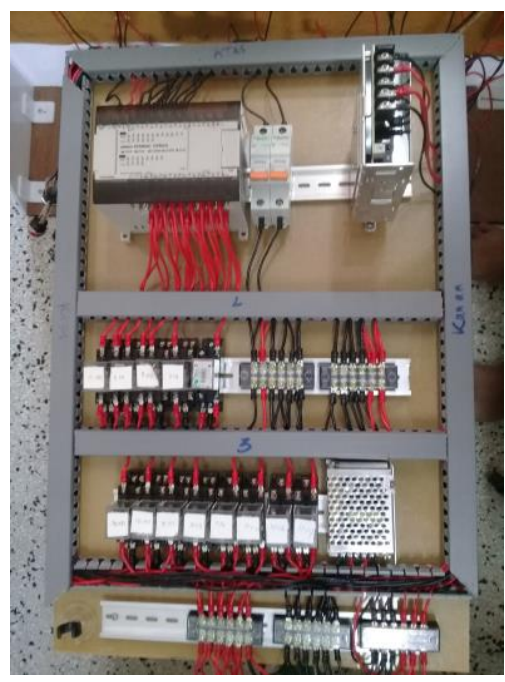

(b)

Figure 10. (a) Fuel oil transfer system prototype and (b) Control panel and wiring system.

As shown in Figure 10, there are output of this research. Figure 10. (a) fuel oil transfer system prototype consists equipments that related to table 1 and table 2, such as pumps, settling tank, service tank, valves.

Figure 10. (b) control panel consists of equipments that could control the system through PLC, such as power supply, PLC, relays, MCB, wiring system.

\section{CONCLUSION}

From the results of running and performed in this research, it can be deduced as follows :

a. Controlling and monitoring of onboard fuel oil treatment system is based on needs for safety and business reason. Automatic control system is recommended by the ship classification society, engine manufacture, and shipping company.

b. In this research, we developed HFO fuel oil system prototype with laboratory scale that work based on real ship. By the prototype and control panel configuration, all the pumps, valve, and censor are successfully controlled as same as the program.

c. Automation fuel oil system was not fully take over the crews responsibility. Ship still need crew to monitoring and standby to avoid error from the system.

d. At full system equipments, there is still a lot of equipments that was not added to the prototype. Such as viscometer, flow meter, purifier, separator, and etc. In real ship, we need more input and output module to control all of the equipment on ship.

\section{REFERENCES}

[1] S. Sarwito, I. R. Kusuma, and B. H. Waramory, 'Design of Automatic Transfer Switch ACOS with Human Machine Interface Monitoring System in Shipboard Application', Int. J. Mar. Eng. Innov. Res., vol. 1, no. 1, Dec. 2016.

[2] 'Analisis Human Error Terhadap Kecelakaan Kapal Pada Sistem Kelistrikan Berbasis Data Di Kapal | Andoyo | Jurnal Teknik ITS'. [Online]. Available: http://www.ejurnal.its.ac.id/index.php/teknik/article/view/9410. [Accessed: 19-Dec-2018]

[3] American Bureau of Shipping, ABS - 31 Notes on Heavy Fuel Oil. American Bureau of Shipping.

[4] 'Speed Optimization Model for Reducing Fuel Consumption Based on Shipping Log Data | Zenodo'. [Online]. Available: https://zenodo.org/record/1128819\#.XBmpx1wzb4Y. [Accessed: 19-Dec-2018].

[5] S. Semin, M. A. Satriawansyah, B. Cahyono, and N. S. Octaviani, 'Analysis of Influence of Masks Flow on Intake Valve of Gas and Oil Fuel Engine Based Simulation', Int. J. Mar. Eng. Innov. Res., vol. 2, no. 3, Jun. 2018.

[6] 'An expert system for aided design of ship systems automation ScienceDirect'. [Online]. Available: https://www.sciencedirect.com/science/article/pii/S09574174000 00646. [Accessed: 19-Dec-2018].

[7] I. R. Kusuma, S. Sarwito, and R. A. W. A. Irawati, 'Analysis of Electric Propulsion Performance on Submersible with Motor DC, Supply Power 10260AH at Voltage 115VDC', Int. J. Mar. Eng. Innov. Res., vol. 1, no. 2, Mar. 2017.

[8] A. J. Seman, 'Next Generation Navy Ship Automation Systems Engineering From Sensors to Systems', in 2005 IEEE International Conference on Systems, Man and Cybernetics, 2005, vol. 2, pp. 1218-1222. 